\title{
ДИСЦИПЛИНАРНАЯ ОТВЕТСТВЕННОСТЬ СОТРУДНИКОВ УГОЛОВНО-ИСПОЛНИТЕЛЬНОЙ СИСТЕМЫ: ВОПРОСЫ ПРАВОПРИМЕНЕНИЯ
}

\section{DISCIPLINARY RESPONSIBILITY EMPLOYEES OF THE PENITENTIARY SYSTEM: LAW ENFORCEMENT ISSUES \\ L. Raschhupkina S. Soloukhina}

Summary: The article deals with the enforcement of disciplinary liability of employees of the penal correction system, is subject to an analysis of the law governing the procedure for imposing penalties on employees of the penal correction system. Special attention is paid by the authors to the identification of theoretical and procedural problems.

Keywords: disciplinary liability, employees of the penal system, law enforcement, violation of official discipline, imposition of a penalty.
A ктуальность выбранной темы неопровержима, поскольку сегодня в современной уголовно-исполнительной системе (далее - УИС) возникает ряд вопросов организационно-правового характера применения дисциплинарной ответственности в отношении ее сотрудников. Служебная деятельность сотрудников УИС связана с соблюдением установленного порядка и служебной дисциплины. Сотрудники, обладая общим статусом гражданина Российской Федерации, имеют и специальный статус для выполнения определенных функций (компетенций). Так, сотрудники могут быть привлечены к юридической ответственности по основаниям, предусмотренным законом. Институт дисциплинарной ответственности исследовался многими теоретиками права и практическими сотрудниками пенитенциарной системы (Ю.И. Калининым, С.Н. Братусь, А.А. Ивановым, А.П. Корневой), однако проблемные вопросы о порядке привлечения к дисциплинарной ответственности и характере наложения взыскания до сих пор не решены. Дисциплинарная ответственность применяется за нарушения трудовой, учебной, служебной, воинской дисциплины.

Следует отметить, что в настоящее время нормативно-правовое регулирование в рассматриваемой сфере несовершенно, что негативным образом сказывается и на имидже уголовно-исполнительной системы, и на правоприменительной деятельности по назначению и исполнению дисциплинарных взысканий, а также мер материального дестимулирования и иных мер принудительного воздействия на нарушителей

\author{
Ращупкина Людмила Валерьевна \\ К.ю.н., Дочент, ВЮИ ФСИН России \\ rashhupkina73@mail.ru \\ Солоухина Светлана Вячеславовна \\ старший преподаватель, ВЮИ ФСИН России \\ svsolona@mail.ru
}

Аннотация: В статье рассматриваются вопросы правоприменения дисциплинарной ответственности сотрудников уголовно-исполнительной системы, подвергаются анализу нормы законодательства, регламентирующие порядок наложения взыскания на сотрудников УИС. Особое внимание авторами уделяется выявлению теоретических и процессуальных проблем.

Ключевые слова: дисциплинарная ответственность, сотрудники уголовноисполнительной системы, правоприменение, нарушение служебной дисциплины, наложение взыскания.

служебной дисциплины. В работе мы остановимся на вопросах, связанных с правоприменением привлечения сотрудников уголовно-исполнительной системы к дисциплинарной ответственности. На сегодняшний день не в должном объеме исследованы базовые понятия и категории административно-служебного права, применяемые в деятельности органов и учреждений уголовно-исполнительной системы: дисциплинарное принуждение в УИС, мера служебно-дисциплинарного принуждения в УИС и другие, не в полной мере определены основные признаки служебно-дисциплинарного принуждения в УИС. Как указывал в своей работе Д.А. Гришин, служебно-дисциплинарное принуждение В органах и учреждениях уголовно-исполнительной системы является сегодня, с одной стороны, базовым административно-правовым институтом, посредством которого обеспечивается режим государственной дисциплины в процессе исполнения государственных функций, возложенных законодательством на Федеральную службу исполнения наказаний, ее территориальные органы и учреждения, с другой - реализуемой в рамках публичных охранительных правоотношений правоохранительной и правоприменительной деятельностью соответствующих должностных лиц ФСИН России по применению мер дисциплинарного воздействия к лицам, нарушающим в УИС служебную дисциплину [3]. Научного анализа требуют такие институты служебно-деликтного законодательства в УИС, как институт аттестации сотрудников, институт служебной проверки в УИС, и процедуры наложения дисципли- 
нарных взысканий и иных принудительных мер на сотрудников УИС.

Для детального изучения проблемных вопросов правоприменения дисциплинарной ответственности к сотрудникам УИС необходимо исследовать ее сущность и теоретический аспект. В соответствии с ФЗ № 197 [1], служба в уголовно-исполнительной системе это вид федеральной государственной службы, представляющий собой профессиональную служебную деятельность граждан Российской Федерации. Поэтому дисциплинарная ответственность сотрудников уголовно-исполнительной системы возникает за нарушение служебной дисциплины. Согласно положением статьи 47 Ф3 № 197, под служебной дисциплиной понимается соблюдение сотрудником установленных законодательством Российской Федерации, Присягой сотрудника уголовно-исполнительной системы, дисциплинарным уставом уголовно-исполнительной системы, правилами внутреннего служебного распорядка учреждения или органа уголовно-исполнительной системы, должностной инструкцией, контрактом, приказами и распоряжениями руководителя федерального органа уголовно-исполнительной системы, приказами и распоряжениями прямых руководителей (начальников) и непосредственного руководителя (начальника) порядка и правил исполнения служебных обязанностей и реализации предоставленных прав.

Под нарушением служебной дисциплины (дисциплинарным проступком) следует признавать виновное действие (бездействие), выразившееся в нарушении сотрудником законодательства Российской Федерации, Присяги сотрудника уголовно-исполнительной системы, дисциплинарного устава уголовно-исполнительной системы, правил внутреннего служебного распорядка учреждения или органа уголовно-исполнительной системы, должностной инструкции, либо в несоблюдении запретов и ограничений, связанных со службой в уголовно-исполнительной системе, и требований к служебному поведению, либо в неисполнении (ненадлежащем исполнении) обязательств, предусмотренных контрактом, служебных обязанностей, приказов и распоряжений прямых руководителей (начальников) и непосредственного руководителя (начальника) при исполнении служебных обязанностей и реализации предоставленных прав.

В рамках научного исследования темы были изучены статистические сведения и судебная практика по привлечению сотрудников УИС к дисциплинарной ответственности на основании Ф3 № 197, представленные территориальными органами. Так, в 2019 году наиболее распространенными нарушениями служебной дисциплины стали:

1. нарушение исполнительской дисциплины - $89,41 \%$
2. коррупционные правонарушения (в том числе предоставление неполных сведений и недостоверных сведений о доходах) - 2,86\%

3. невыход на службу без уважительных причин - 1,2\%

4. утрата служебных удостоверений $-0,14 \%$

5. прочие нарушения $-6,3 \%$

Однако по фактам допущенных сотрудниками нарушений служебной дисциплины привлечены к дисциплинарной ответственности только две трети от общего количества правонарушений, что подтверждает наличие проблем организационно-правового характера привлечения сотрудников УИС к дисциплинарной ответственности, возникших с момента вступления в действие вышеуказанного закона.

На наш взгляд, сложность правоприменения дисциплинарной ответственности состоит в том, что действующие нормы права, регламентирующие порядок привлечения сотрудников УИС к ответственности, не разграничивают виды дисциплинарной ответственности. К числу таковых относятся следующие нормативные правовые акты: Закон РФ от 21 июля 1993 г. № 5473-1 «Об учреждениях и органах, исполняющих уголовные наказания в виде лишения свободы», Федеральный закон от 19 июля 2018 г. № 197-Ф3 «О службе в уголовно-исполнительной системе Российской Федерации и о внесении изменений в Закон Российской Федерации «Об учреждениях и органах, исполняющих уголовные наказания в виде лишения свободы» (именно ст. 15), КоАП РФ, УК РФ, также иные локальные нормативные акты, регламентирующие дисциплину и порядок прохождения службы в конкретных субъектах Российской Федерации [4].

Отметим, что, в соответствии с Федеральным законом «О службе в УИС», сотрудник за совершение административного правонарушения несет дисциплинарную ответственность, за исключением административного правонарушения, за совершение которого сотрудник подлежит административной ответственности на общих основаниях, в соответствии с Кодексом Российской Федерации об административных правонарушениях.

Добавим, за одно и то же правонарушение сотрудник дважды не привлекается к ответственности. Вопрос такой тенденции неоднозначен. Так, если административная ответственность в основном выражается в штрафных санкциях, при этом в объективных денежных суммах, то дисциплинарная - предполагает взыскания, которые выражаются в определённых ограничениях и лишениях в служебной деятельности, например, лишение премии, стагнация в продвижении по службе и в званиях. При этом список дисциплинарных взысканий четко определен в статье 50 Ф3 № 197, среди которых: замечание; выговор; строгий выговор; предупреждение о неполном служебном соответствии; увольнение со службы в 
УИС. Как видим, законодатель разместил их по нарастанию юридических последствий, наступающих для сотрудников УИС. Анализ данной статьи указанного Ф3 показывает, что перечень дисциплинарных взысканий, применяемых к сотрудникам УИС, достаточно широк и во многом, как отмечалось ранее, терминологически не определен. Если рассматривать фактические последствия отдельных дисциплинарных взысканий, то можно выявить причинно-следственную связь, связанную с отсутствием четкого разграничения понятий «замечание», «выговор», «строгий выговор» и «предупреждение о неполном служебном соответствии». Сразу оговоримся, что ни законодательство о государственной службе, ни трудовое законодательство, ни ведомственные нормативно-правовые акты не закрепляют указанных терминов и не определяют оснований их дифференциации по видам проступков и особенностей применения.

Еще одной актуальной проблемой является отсутствие законодательного закрепления дефиниции дисциплинарного проступка сотрудника УИС, которое бы четко отграничивало его от иных видов правонарушений. В результате сложившейся ситуации квалификация противоправного деяния либо как дисциплинарного проступка, либо как должностного преступления производится безосновательно по усмотрению уполномоченного принимать решение должностного лица. Как было отмечено ранее, возможность одновременного применения административных и дисциплинарных санкций за одно деяние ограничивается федеральным законодательством.

Все это, на наш взгляд, затрудняет достижение главной цели профессиональной деятельности сотрудников УИС - поддержание служебной дисциплины. Таким образом, можно констатировать, что в правоприменительной деятельности учреждений ФСИН России, связанной с привлечением сотрудников к дисциплинарной ответственности по основаниям Ф3 № 197, возникает ряд трудностей:

- во-первых, отсутствие перечня общих нарушений служебной дисциплины, связанных с прохождением службы;

- во-вторых, отсутствие правовой регламентации процедуры наложения дисциплинарных взысканий;

- в-третьих, отсутствие однозначного толкования исчисления сроков проведения служебных проверок;

- в-четвертых, отсутствие механизма и порядка привлечения к дисциплинарной ответственности сотрудников за коррупционные правонарушения;

- в-пятых, отсутствие правовой регламентации порядка применения и учета таких мер дисциплинарного взыскания, как: объявление публично в устной форме дисциплинарного взыскания в виде замечания или выговора.
Важным направлением в органах и учреждениях УИС является дисциплинарная практика, которая имеет особое значение. Так, например, совершение противоправного деяния сотрудником УИС напрямую влияет на авторитет всей уголовно-исполнительной системы. В общественном мнении это соотносимые понятия: по одному грубому нарушению оценивают весь коллектив сотрудников.

Стоит отметить, значимость дисциплинарной ответственности возросла с принятием нового ФЗ № 197 и Дисциплинарного устава УИС. Так, Дисциплинарный устав УИС [2] определяет:

а) обязанности сотрудников по соблюдению и поддержанию служебной дисциплины;

б) права, обязанности и ответственность руководителей (начальников) по поддержанию служебной дисциплины;

в) обязательность исполнения приказа руководителя (начальника);

г) порядок наложения и исполнения дисциплинарных взысканий;

д) порядок учета мер поощрения и дисциплинарных взысканий;

е) порядок обжалования дисциплинарных взысканий.

Однако, отметим, что данные нормативные правовые акты не способствовали регламентации института дисциплинарной ответственности сотрудников УИС. Обратим внимание, действующие правовые нормы не содержат перечня деяний, признаваемых дисциплинарными проступками. Это создает трудности в применении мер дисциплинарного воздействия за служебные нарушения в подразделениях ФСИН России и в разрешении практических ситуаций, связанных непосредственно с процедурой наложения дисциплинарных взысканий.

Таким образом, проанализировав практику привлечения сотрудников УИС к дисциплинарной ответственности в учреждениях и органах УИС, есть основание полагать, что нарушения служебной дисциплины с высокой степенью вероятности допускаются, в том числе, по причине несовершенства и противоречий административно-правового регулирования дисциплинарной ответственности. В этой связи возникает объективная необходимость законодательного совершенствования правовых актов, действующих на сегодняшний день, а также совершенствования правоприменительной деятельности. На наш взгляд, с целью урегулирования порядка проведения служебных проверок в учреждениях и органах уголовно-исполнительной системы необходимо принять соответствующий подзаконный акт, что в целом позитивно отразится на поддержании служебной дисциплины сотрудников. 


\section{ЛИТЕРАТУРА}

1. Федерального закона от 19.07.2018 № 197-ФЗ «0 службе в уголовно-исполнительной системе Российской Федерации и о внесении изменений в Закон Российской Федерации «0б учреждениях и органах, исполняющие уголовные наказания в виде лишения свободы» // [Электронный ресурс]. - Режим доступа: URL:https://base.garant.ru/71992738/

2. Приказ Минюста России от 12.09.2019 № 202 «0б утверждении дисциплинарного устава уголовно-исполнительной системы Российской Федерации (Зарегистрировано в Минюсте России 17.09.2019 № 55944) // [Электронный ресурс]. - Режим доступа: URL: http://www.consultant.ru/document/cons_ doc_LAW_333557/

3. Гришин Д.А. К вопросу о понятии и содержании служебно-дисциплинарного принуждения в уголовно-исполнительной системе // Административное право и процесс. 2018. № 6. С. 33.

4. Никифоров А.В. Дисциплинарная ответственность сотрудников органов внутренних дел: Дис. ... канд. юрид. наук. Омск, 2018. С. 26-27.

○ Ращупкина Людмила Валерьевна (rashhupkina73@mail.ru), Солоухина Светлана Вячеславовна (svsolona@mail.ru).

Журнал «Современная наука: актуальные проблемы теории и практики»

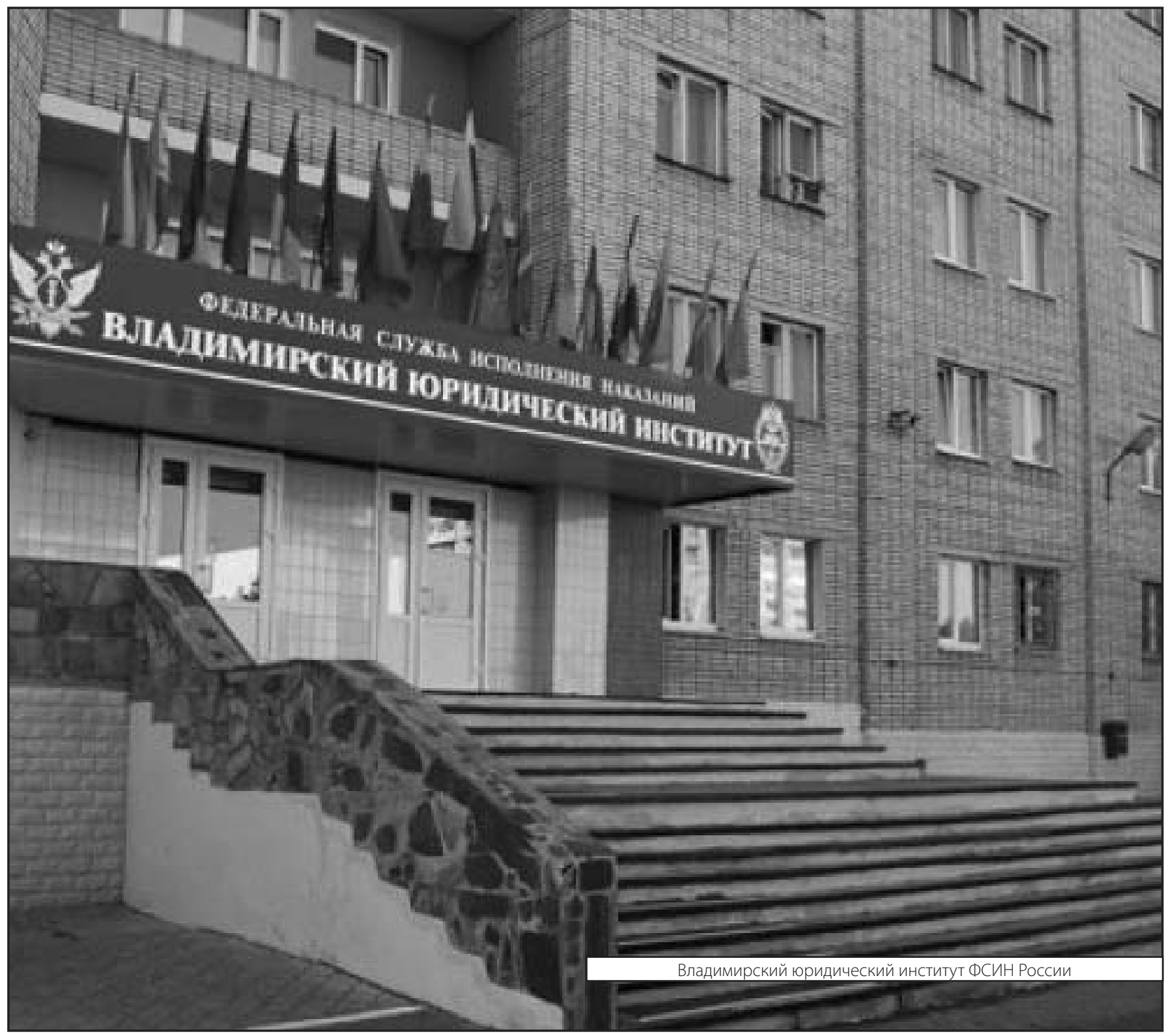

